\title{
Determinants of satisfaction and turnover of staff in hotel enterprises
}

\section{Fatores determinantes da satisfação e rotatividade de colaboradores em empreendimentos hoteleiros}

\author{
Érica Aparecida Coelho' ${ }^{1}$ (1) \\ Tereza Angélica Bartolomeu² (1)
}

\section{GESTÃO PRODUCÃ̃O}

ISSN 0104-530X (Print) ISSN 1806-9649 (Online)

\begin{abstract}
How to cite: Coelho, E. A., Bartolomeu, T. A. (2019). Determinants of satisfaction and turnover of staff in hotel enterprises. Gestão \& Produção, 26(3), e3142. https://doi.org/10.1590/0104-530X3242-19
\end{abstract}

\begin{abstract}
The aim of the present study was to evaluate the existing relationship between Quality of Life at Work (QWL) and personal quality of life, identifying factors that determinate the satisfaction and the employees' turnover in hotel business. The high turnover of staff in the hotel business is a reality and eventually it is related to the payment offered by the sector, however, it is not only dependent on this aspect. The methodological approach included structured questionnaire, semi-structured interview and Likert-type scale structured questionnaire. The identified factors were related to the working environment and payment, which affect the employees' satisfaction, the commitment to the contracting company, the quality of the work performed and also the staff turnover. The results showed that the hotels which offered better working conditions brought positive changes to their working environment, improved the quality of the selling product and the employees' quality of life, increased customers' satisfaction, reduced the staff turnover and raised the company profit.
\end{abstract}

Keywords: High quality of life at work; High personal quality of life; Customers satisfaction; Employees' turnover; Hotel business.

Resumo: O presente estudo objetivou verificar a relação existente entre Qualidade de Vida no Trabalho (QVT) e qualidade de vida pessoal, identificando fatores que determinam a satisfação e a rotatividade de colaboradoras em empreendimentos hoteleiros. A alta rotatividade no setor hoteleiro é uma realidade e, por vezes, está atrelada a remuneração oferecida pelo setor, porém, não está condicionada somente a esse aspecto. Procurou-se, por meio desse estudo, identificar os fatores geradores da satisfação ou insatisfação (rotatividade) das colaboradoras. Os instrumentos metodológicos utilizados foram questionário estruturado, entrevista semiestruturada e questionário estruturado em escala tipo Likert. Os fatores identificados estavam relacionados ao ambiente de trabalho e à remuneração, os quais interferem na satisfação das colaboradoras, no comprometimento com a empresa contratante, no trabalho desenvolvido assim como na rotatividade. Constatou-se nos hotéis pesquisados que, aqueles que procuravam oferecer melhores condições de trabalho na sua prática diária proporcionavam mudanças positivas no seu ambiente laboral, melhorias no produto ofertado e na qualidade de vida das colaboradoras, maior satisfação dos clientes, menor rotatividade, promovendo inclusive maior lucratividade.

Palavras-chave: Qualidade de vida no trabalho; Qualidade de vida pessoal; Satisfação; Rotatividade; Hotelaria.

\section{Introduction}

The emergence of the means of lodging is confused with the emergence of means of transportation, since "the hotel industry began with the first displacements of the human beings who sought accommodation" (Bühler, 2009, p. 21).
For Duarte (2008, p. 25), the hotel sector "[...] had the initial basic function of housing those who, because they were outside their home, needed a room, a bed and a good bath". Nowadays, in addition to these services, guests are offered

\footnotetext{
${ }^{1}$ Programa de Pós-graduação em Economia Doméstica, Departamento de Economia Doméstica, Universidade Federal de Viçosa UFV, Avenida Peter Henry Rolfs, s/n, Campus Universitário, CEP 36570-900, Viçosa, MG, Brasil, e-mail: erica.coelho@ufv.br

${ }^{2}$ Departamento de Economia Doméstica, Centro de Ciências Humanas Letras e Artes, Universidade Federal de Viçosa - UFV, Avenida Peter Henry Rolfs, s/n, Campus Universitário, CEP 36570-900, Viçosa, MG, Brasil, e-mail: angelica@ufv.br
}

Received June 9, 2016 - Accepted Aug. 8, 2017

Financial Support: CAPES. 
food, leisure and differentiated services adapted to the target public.

According to data from the CAGED of the Labor and Employment Ministry - MTE (Brasil, 2015a, b), in Brazil, in May 2015, 217.179 people were admitted to work at housing, food, repair, maintenance and writing services, on the otherside, 226.269 employees were dismissed, thus obtaining a negative balance of 9,090 layoffs. In Minas Gerais there were 21,057 admissions and 21,550 disconnections in this sector. In the municipality of Viçosa, in May 2015, there were 108 admissions in accommodation, food, repair, maintenance, writing and 67 shutdowns. There is a high turnover of employees in this sector.

One of the reasons for this high turnover may be the low remuneration offered by the hotel sector. For Hazin \& Cols (2000), as mentioned in Magalhães (2006), the low remuneration offered for the operational positions of tourism and hotel industry can be explained in part by the shortage of qualified personnel. Low pay associated with low qualification is something present in almost all the Brazilian cities and mainly in the northeast region. Magalhães (2006), affirms that this is a vicious cycle, in which the company does not offer an adequate salary, because the employee does not present the desired qualification, on the otherside the employee does not have the desired qualification, because the company does not offer or not available means of obtaining it.

It is remarkable the importance of the hotel sector in the economy and the need for constant search for quality of services and satisfaction of its consumers. Farias (2008) emphasizes that the quality of the services provided is the best way of insertion and permanence in the highly competitive market. Quality is a primary factor for customer satisfaction in general, and in this way the hotel industry must provide the means to maintain a level of quality in all its sectors and services.

Kotler \& Keller (2006), as cited in Branco et al. (2010), define satisfaction as the sensation of pleasure felt by the customer when comparing their initial expectations about a product and the true performance achieved.

Customer satisfaction is a great concern on the part of entrepreneurs, their loyalty and guarantee of good income, by offering services with a high level of quality. Magalhães (2006) believes that, moreover, the customer of the hospitality market "seeks the intangible and this intangibility can be in the smile of the worker, in the way that he leads the service and in the expectation that everything be magical. She adds that the means of accommodation seek to offer pleasure and well-being to its guests. In this way, "[...] well-being and pleasure should be part of the exercise of activity". Unfortunately, the concern of most companies is in their efficiency, forgetting the well-being of the workers.

The welfare experiences that lead to the Life's Quality at Work are reduced by blindness, or should I say myopia promoted by the eagerness for constant profits and at any cost (Magalhães, 2006, p. 4).

Quality of Life at Work (QWL) is a key factor in organizations, having a crucial importance for the development of companies, especially in terms of increasing quality, productivity and organizational competitiveness, since people are "pieces" and "gears" fundamental to the functioning of a company. Supporting this idea, Fernandes (1996) states that the application of QWL leads to better performance and at the same time leads to less waste, reducing operational costs.

QWL presents a direct relationship between quality of life in the work environment and in personal life, since job satisfaction can not be dissociated from the individual. According to Mendes \& Leite (2008) there is an inseparable relationship between QWL and global quality of life. According to Mendes \& Leite (2008) there is an inseparable relationship between QWL and global quality of life. "QWL is a vital point, not only for the achievement of man at work, but also in all his existence" (Mendes \& Leite, 2008, p. 160).

In order for an organization to achieve high levels of productivity and performance, it requires people who work in it to be motivated and committed to the development of their activities and rewarded for them (Chiavenato, 2010). However, in order for this triad: individual, work and organization to move towards organizational competitiveness, it is necessary to invest in QWL.

Therefore, from these considerations, it is possible to highlight the importance of this study that sought to verify the relationship between quality of life at work (QWL) and personal quality of life, identifying factors that determine the satisfaction and turnover of employees in hotel developments.

This article is part of the master's thesis developed with the Graduate Program in Domestic Economy of the Federal University of Viçosa-MG.

\section{Theoretical reference}

To understand the dynamics of the proposed discussion, it is necessary to present and discuss aspects relevant to the theme, such as personal quality of life; quality of life at work; hotel sector and turnover in this sector.

\subsection{Personal quality of life}

The term quality of life originated in the political context and began to be used in the 1960s, and in 1964 Lyndon Johnson, President of the United States, 
used this term in his speech stating that " $[\ldots]$ goals can not be measured through balances of banking institutions. They can only be measured by the quality of life they provide to people" (Abrams, 1974 as quoted in Pires, 2007, p. 36).

For Minayo et al. (2000) quality of life is a highly human conception,

$[\ldots]$ which has been approximated to the degree of satisfaction found in family, love, social and environmental life, and to existential aesthetics itself. It presupposes the ability to make a cultural synthesis of all the elements that a given society considers its standard of comfort and well-being. (Minayo et al., 2000, p. 2).

The notion about quality of life is relative, however Minayo et al. (2000, p. 2-3) have at least three reference forums: first, historical, where, in a given time of their economic, social and technological development, a specific society has a different quality of life parameter of the same society in another historic step. "Second, the cultural, where "values and needs are constructed and hierarchized differently by the people, revealing their traditions". And the "third aspect refers to stratification or social classes".

According to the World Health Organization Quality of Life Study Group, quality of life is

[...] the individual's perception of their position in life in the context of the culture and value system in which they live and in relation to their goals, expectations, standards and concerns (Fleck et al., 2000, p. 179).

With the aim of improving the quality of life, family members from different social strata are taking on work and other tasks outside the home, generating an accumulation of functions with activities inside and outside the home. Reality lived mainly by women. Therefore, means are needed to reconcile domestic work and paid work.

Some entrepreneurs are investing in the quality of life at work, aiming, in principle, the profit of the company. However, this also enables improvements in the quality of life of its employees, both inside and outside the company.

\subsection{Quality of life at work}

Quality of life at work can be understood as a program that aims to facilitate and satisfy the needs of the worker when developing their activities in the organization, having as basic idea the fact that people are more productive when they are more satisfied and involved with their work (Conte, 2003).

According to Chiavenato (2010, p. 448), "the term QWL was coined by Louis Davis in the 1970s when he was developing a project on job design."
For him, the concept of QWL is related to the general well-being and health of workers in the development of their work activities.

QWL is a worrisome issue for many companies, especially those looking to be highly competitive in an increasingly globalized marketplace like the hotel industry. In the certainty that the human being is the agent responsible for the success of every business, these organizations see in the QWL a question of organizational competitiveness (Fernandes, 1996). Following this reasoning, Ferreira et al. (2009, p. 320) affirm that "it is not enough to guarantee the final quality of products and services; it is vital that it be accompanied by quality of life at work, considering the employees."

The definitions of QWL range from medical care and work safety to voluntary activities involving employees and employers in areas such as leisure, motivation, and so on. Most of them discuss the conditions of work, the well-being of the individual and groups (Limongifrança, 2004 as quoted in Rugiski et al., 2005).

Fernandes (1996) is one of the pioneers in the study of QWL in Brazil, in his studies he relates this concept to organizational management. The author states that when thinking about QWL,

$[\ldots]$ it is necessary to look at a range of factors
that, when present in a work situation, are reflected
in the individual's satisfaction and participation,
mobilizing their energies and actualizing their
potential (Fernandes, 1996, p. 27 ).

The author also argues that the QWL can be used as a means of renewing the forms of organization at work, so that when the level of worker satisfaction increases, at the same time, productivity also rises.

Medeiros \& Ferreira (2011, p. 12) point out that "[...] the theme of Quality of Life at Work is endowed with semantic elasticity and [is] a characteristically nomadic and multidisciplinary concept". There is no consensus in the definitions on the subject, besides a generalist character, which generates important and not always positive implications for the production of knowledge on this topic.

In this way, it is affirmed that the QWL

[...] dialogues with notions such as motivation, satisfaction, health and safety at work, involving more recent discussions about new forms of work organization and new technologies (Sato, 1999 as quoted in Lacaz, 2000, p. 152).

For Ribeiro \& Campos (2009, p. 29), the studies that approach QWL are translated into a

[...] way of understanding the work process and its impacts on the employee's life, both on the professional side - whether through productivity, absenteeism, turnover - as well as on the personal 
side - illnesses, dissatisfaction, internal conflicts among others (Ribeiro \& Campos, 2009, p. 29).

In other words, Chiavenato (2010) concludes that, in order to satisfy its client, the organization has the primary need to satisfy its employees by paying due attention to the human needs that vary according to the culture of each individual and each organization. Not being the QWL determined only by

[...] individual characteristics (needs, values, expectations) or situational (organizational structure, technology, reward systems, internal policies), but rather by the systemic performance of these characteristics (Chiavenato, 2010, p. 450).

Bom Sucesso (1998) points out that the most important factors for the existence of QWL are: satisfaction with the profession, values and practices characteristic of the organizational culture of the company and the family structure. They also add that interpersonal relationships, conflicts, the way a person relates to a team, their self-esteem, and the way they feel about themselves affect job satisfaction. Their

[...] life history and factors related to organizational variables result in attitudes that hinder or facilitate labor relations, intensifying concern and responsibility for the promotion of QWL (Bom Sucesso, 1998, p. 29).

Walton (1973) as quoted by Zaratini \& Padilha (2010), Schmidt (2009), Höpner (2008) and Magalhães (2006) synthesize the QWL into eight conceptual categories:

(1) adequate and fair compensation: compensation may depend on several factors, but must live up to the effort expended by the worker;

(2) safe and healthy working conditions: working conditions appropriate to the health and well-being of employees;

(3) opportunities for use and development of human capacities: offering opportunities that enable the development of worker skills, emphasizing their autonomy and participation;

(4) future opportunities for continued growth and job security: opportunity for professional growth;

(5) social integration in the organization: dissolution of outstanding hierarchies, mutual support, frankness among all and non-discrimination;

(6) constitutionalism in the organization: workers' rights and duties;

(7) work and total space of life of the individual: work-life balance, where work should not occupy all the time and energy of the worker, harming his family life;

(8) social relevance of work in life: characteristics of the company that produce pride and self-esteem in the worker.

The offer of QWL is relevant for companies that wish to win customers through quality services, in addition, it translates a way to generate greater satisfaction for the external and internal customer.

\subsection{Hospitality and turnover}

It can be said that the hotel industry was born "in the nineteenth century, and considered the Hotel Tremont House, built in Boston, Mass, in 1819" as the principle of the modern hotel industry (La Torre, 2001, p. 19).

The national hospitality industry is growing every day and generating jobs for many people. Hotels are being built more and more for the purpose of comfort, convenience and satisfaction for the guest (Cândido \& Vieira, 2003, p. 39).

For Medlik \& Ingram (2002) hotels play an important role in the economy by generating thousands of jobs in the various areas that are part of this sector, providing an important alternative where there is unemployment and contributing to regional development.

Branco et al. (2010) state that the hotel service can be a representative example of the tertiary sector and customer satisfaction as a differentiator in market competitiveness. He adds that it is a service that accompanies the accelerated development of the tourism industry.

The Brazilian hotel industry is under increasing modernization. Quality, customer satisfaction, the introduction or expansion of new services and technologies, among others, and their employees are directly involved in the success or failure of these issues.

For Bühler (2009, p. 15),

$$
\begin{aligned}
& {[\ldots] \text { organizations should increasingly value human }} \\
& \text { capital, its potential and its competencies, because } \\
& \text { the differential in competitiveness is related to the } \\
& \text { quality of service provision. }
\end{aligned}
$$

One of the most important aspects considered in the hotel sector is the team of employees, because it is the main product offered that is the accommodation, that is, the attendance, reception, room and all other services offered. Bühler (2009) emphasizes that all the details must be taken into account, from aspects related to the external appearance of the building to the rigor of cleanliness and hygiene. And he adds that, "[...] the human resources sector is one of the main references of the hotel administration. The service performed by its employees represents 
the performance of the hotel organization" (Bühler, 2009, p. 16).

It is known that the good performance of the organization or the quality of services offered is directly related to QWL that includes aspects such as motivation, satisfaction, well-being, personal and professional fulfillment among others. Thus, a way to maintain an efficient functioning and the permanence of the employees depends on the internal politics of the company.

According to Mullis (2001, p. 271), as cited in Bühler (2009, p. 64) "[...] in the hospitality business, employee turnover is admittedly high, especially when compared to other areas of activity".

Magalhães (2006, p. 2) believes that the requirements directed to the tourism professional end up embodying "human variability" and lead some individuals to "[...] deny their personal characteristics, values and feelings in the name of a 'necessary hospitality' and thus survive in this segment". However, not everyone can achieve and maintain such behavior. Bühler (2009) states that one of the hypotheses for the employee's request for dismissal concerns dissatisfaction with some internal politics, lack of motivation and the search for better positions.

It is important that hotels provide means of keeping the contributor satisfied and thus, also, contentment in the client's stay. In addition, the motivated employee is loyal to your company, works with pleasure and wants to keep on the job. Bühler (2009) argues that inadequate human resource management generates employee turnover or turnover due to internal conflicts and worker disengagement.

Höpner (2008, p. 60) concludes that

$[\ldots]$ the instability or high turnover presented by the workers in the lodging sector may be related to the low salaries practiced and the low level of education of most professionals in this area, when compared to the others tourism industry.

\section{For Zaratini \& Padilha (2010)}

[...] the workload is high and the difficulty of reconciling free time with family leisure is evident, given the incompatibility of the clearances. Because of this, employee turnover is high, as it is difficult to find people willing to withstand the wear and tear of work (Zaratini \& Padilha, 2010, p. 212).

Another factor associated with the high employee turnover is the low salary offered. Companies that do not value their employees financially have high turnover (Bühler, 2009).

According to Schweitzer (2003, p. 1) "[...] employee turnover is often cited as one of the factors contributing to the failure of a firm's employee productivity rates relative to its competitors". For Bühler (2009, p. 17) a high turnover generates "[...] reduction of productivity, profitability and organizational health".

The high turnover causes serious problems for the hotel company, mainly because it is a competitive market. According to Schweitzer (2003), the employee who works in a company with high turnover feels insecure and works unmotivated, not giving the guest everything that could be presented.

Bühler (2009, p. 17) believes that

[...] this decline in staffing leads to loss of knowledge, intellectual capital, intelligence, process control, customer connections, market, business, training investments and financial resources.

That is, the employee loses his job and his source of income and the company loses the investment destined to that employee and to replace that employee.

By identifying the causes of turnover, it is possible to correct them in order to reduce it and consequently increase the quality of the services provided, but Bühler (2009, p. 91) adds that

[...] small turnover rates are admissible because they incorporate new people to the company and help to renew the work environment and improve the quality of services.

Since employee motivation reduces turnover, Schweitzer (2003) believes that motivated and talented employees need to participate in the company's decisions, as well as their contributions put into practices, helping to maintain job satisfaction and permanence. In addition, a good QWL generates employee satisfaction, enabling improvements in productivity, quality of service and personal quality of life. This captivates the client and reduces employee turnover, generating greater stability and profitability for the company.

\section{Methodology}

Next, the methodology used in this study will be presented, regarding population, type of research and data collection.

\subsection{Population}

The study population was formed by women and hotel managers/owners of Viçosa-MG who authorized the research. For Cabral (s.d.) as quoted in Costa et al. (2011, p. 40), the female profile best fits the hotel industry because the activity "requires sensitivity and organization". It is necessary to have with the guests "agility, organization and great delicacy". "Women have conquered the labor market, and in hospitality, they are essential for their versatility." These are professionals of great value in the daily activities of a hotel, so it is necessary to study their perceptions about aspects related to the work developed.

The universe of the present research consisted of the 13 hotels identified in the municipality of Viçosa-MG. Of these, 9 participated in the research, 
3 refused to participate. Only one of the hotels was excluded because it is a family business, whose operation takes place in the owners' home, being the only employees of the establishment. Thus, work and personal life mingled.

In total, 57 interviews were conducted with the women who became available to participate in the survey, as well as the managers/owners of the analyzed hotels. Among the interviewees, 48 were collaborators in different functions in the hotels (maid, receptionist, cooks etc.), 4 female managers/owners and 5 male managers/owners.

\subsection{Type of research}

The present study presents qualitative and quantitative aspects; therefore the methodology is mixed. According to Minayo and Sanches (1993, p. 247) "[...] the quantitative study can generate questions to be qualitatively deepened, and vice versa [...]", and can thus act as complementary methodologies.

As the hotels in this city are micro - commerce companies and services that have up to 9 employees (SEBRAE, 2017) and small - commerce and services that have 10 to 49 employees (SEBRAE, 2017), and due to the nature of the study, the case study was chosen as a qualitative research method. The case study, according to Silva (2006), has the advantages of investigating a phenomenon within the context of the lived reality, exploring real-life situations, whose limits are not clearly defined, besides describing the situation of the context in which it is being done research.

This method is characterized by the study of one or a few objects, so as to allow a wide and detailed knowledge, comparable to other contexts and situations already investigated, considering the proposed theme for the study (Gil, 2008).

The aim was to analyze the quality of life in the work and in the personnel life of women who work in hotels, aiming to identify some relation of these with the high turnover in the work present in the mentioned sector. In this sense, it is also a descriptive research. According to Rampazzo (2005, p. 53), this type of research seeks to "[...] discover, with the possible precision, the frequency with which a phenomenon occurs, its relation and its connection with others, its nature and its characteristics".

\subsection{Data collect}

Before being executed, the project was submitted and approved by the Ethics Committee in Research with Human Beings of the Federal University of Viçosa, aiming to ensure its compliance with the universal guidelines of ethics in scientific research. The employees' participation occurred after signing the Authorization Term of the managers / owners of the hotels in which they worked. The participation in the interviews was due to the voluntary signature of the Term of Free and Informed Consent.

In order to trace the socioeconomic profile of the women investigated, a structured questionnaire was used. The questionnaire was about age, schooling, place of birth, place of residence, marital status, family responsibility, number and age of family members residing in same household, income, previous experience, length of service, form of hiring, etc.

In order to know the factors related to the QWL, a semi-structured interview script was used with 18 questions that addressed the QWL collaborators' view regarding their importance, work environment, development of activities, qualification, incentives, working hours, calendar of holidays, signature of the portfolio, etc. A structured questionnaire was also used, divided in 6 blocks of questions related to: social integration, compensation, working conditions, health, incentives, working hours and participation. The preparation of the instrument was based on a study by Silva (2006), which used a 5-point Likert scale.

In order to know the collaborators' conception of their personal quality of life, a semi-structured interview script was used, consisting of 08 questions that dealt with the perception of quality of life, important factors to have quality of life, time management at home, routine, priority activities at home, developed and desired activities on days off. We also used two blocks of structured questions, on a Likert scale, that dealt with social integration and acquisition of goods.

In order to verify how the managers/owners analyzed the turnover and QWL, a semi-structured interview was conducted with the hotel manager or owner, with 17 questions related to the characterization of the interviewee profile, perceptions about QWL, evaluation and importance of QWL, work environment, existing limitations, qualification, incentives, working hours, work schedule, signature of the work card, turnover, etc.

\subsection{Data analysis}

Content analysis was used to "understand the construction of meaning that social actors express in discourse" (Silva et al., 2005, p. 74). Trivinos (1987) as quoted in Silva et al. (2005, p. 75), explains the three steps pointed out by Bardin (1994), as being fundamental in the work with content analysis, these being:

The pre-analysis: organization of all materials that would be used for data collection, as well as other materials that would aid in understanding the phenomenon analyzed and "to establish what the author defines as a corpus of the investigation, 
which would be the specification of the field that the researcher must focus attention ".

The analytical description: stage where the "material gathered which constitutes the corpus of the research is analyzed in depth, being guided in principle by the assumptions and the theoretical framework, arising from this analysis frames of references" who "seek coincident and divergent synthesis of ideas".

Referential interpretation: it is the phase of analysis itself, in which "reflection, intuition, based on empirical materials, established relations with reality by deepening the connections of ideas, arriving if possible to the basic proposal of transformations in the limits of specific and general structures."

These three phases guided the process of data organization and analysis of the content of the present study.

As for the quantitative data, these were operationalized and analyzed according to a scale (Table 1) proposed by Pereira et al. (2001) as quoted in Silva (2006) and adapted to the present research.

The quantitative data were tabulated and analyzed through descriptive statistical analysis (citation frequency) and by systematic description and interpretation procedures.

The analysis of the data was guided by the study of the profile and perceptions about QWL and personal quality of life. Based on these analyzes, we sought to infer the relationship between factors related to QWL and personal quality of life that modify motivation, commitment, and turnover.

The interpretation of the data was primordial and related to the corpus of the investigation, in order to be validated by the scientific community.

\section{Results and discussions}

Initially, we sought to characterize the group of 52 women interviewed. Their age ranged from 20 to 65 years, and the majority, $63.5 \%$ (33), were aged between 30 and 49 years. These women mainly occupied positions related to the organization, cleaning and preparation of food. The majority, $61.5 \%$ (32), had completed higher education, or completed high school or was doing professionalization courses,

Table 1. Scale for interpretation of satisfaction level in relation to QWL.

\begin{tabular}{cc}
\hline QWL & Interpretation \\
\hline 1.0 & Very Unsatisfied \\
2.0 & Unsatisfied \\
3.0 & Neutral \\
4.0 & Satisfied \\
5.0 & Very Satisfied \\
\hline
\end{tabular}

Note: Source: Adapted from Pereira et al. (2001) as quoted in Silva (2006) . aiming for professional and salary improvement. $53.8 \%$ (28) were married, $21.1 \%$ (11) were single, $13.5 \%$ (7) divorced or separated and $11.5 \%$ (6) lived in a stable union. $44(84.6 \%)$ of the interviewed women had homes made up of 2 to 4 members. The age of the members who constituted the families of the interviewees ranged from 4 months to 82 years. The majority of these $(85 \%)$ were in the range of 11 to 60 years.

After investigating the perceptions of the collaborators and managers / owners about QWL, it was verified that QWL was associated mainly with the work environment and internal communication, the relationship among the work colleagues, the desire for the activity performed, besides the structure and dynamics of the work team (number of employees, breaks, overtime, etc.). Each of these aspects contributed to satisfaction, with QWL and low turnover. All these aspects, added to the attendance of the labor rights, adequate salaries, professional perspective and permanent qualification showed to guarantee the motivation of the collaborators.

The employees of the analyzed hotels attributed the worst evaluations in the satisfaction scale to the following aspects: salary, facilities for personal use and storage of work tools, medical care provided to their relatives, physical and mental exhaustion during the development of the task, training offered by the company, possibility of being promoted and encouraged by the company to study.

It is important to emphasize that there are no laws that guarantee the presence of these aspects in a company. Only a management that values the quality of its services, image of the company and that worries about its employees, seeks to offer means to promote a good QWL, because it recognizes that this will generate profits, coming from customer satisfaction and avoiding turnover.

The evaluation of the social integration of these collaborators obtained the best scores. However, the variables related to compensation, working conditions, health and working hours presented positive results, but not very high. Therefore, it is judged that the collaborators interviewed were satisfied, but that much still can be done to improve the work environment and ensure a good QWL, satisfaction, motivation and consequently lower turnover.

It is important to mention that the hotels investigated were concerned with guaranteeing the employees' labor rights, the salary payment and the offer of benefits (transportation voucher, food voucher, bonuses, etc.), which are important and fundamental factors for the of the employee in that place of work. However, not all of them showed their collaborators how important they were to maintaining and improving the company, nor how much they cared about them as a person, 
taking into account their desires and aspirations, listening to them.

It was found that these attitudes produced a positive effect greater than the salary and the benefits offered, because even when offering a more attractive salary, there is always the doubt about the environment and its valuation in a new workplace. This is due to the fact that many of them have already internalized the reality of not receiving higher salaries because of their low level of education, as can be seen in the following statement:

[...] I can not complain (because of the salary) because if I want a better job I would have to study, so I have to be satisfied or look for something better, as I do not have, I did not study, I have to stay right here (C2, T, 47 years).

In relation to personal quality of life, a strong relationship with the family, satisfaction with herself and with work was noted. About family, it was possible to highlight the importance of harmony and family coexistence, good relationship with the people close to us. Self-satisfaction was translated more into spiritual matters, physical and mental health, freedom to live, and self-confidence. It was verified that the work enabled a personal quality of life when it provided satisfaction to those who performed it, adequate income able to generate family support, housing, leisure and the realization of desires and dreams. When the work meets the needs of the employee, the turnover is lower, since he (the work) fulfills its functions.

Personal quality of life evidenced the best results regarding the satisfaction related to the acquisition of goods and showed dissatisfaction with the time that these employees had to be with their family and for leisure due to the time dedicated to work. Some interviewees revealed that the shortage of time was also a factor that limited access to education, as the following statement reveals:

I wish I had more time to study, I really enjoy studying, and my work schedule does not allow me to. Not only working hours, but also my condition as the only provider in the house. My only schedule would be the night, and I can not leave because I have to stay at home to take care of my daughters (R14, N, 35 years).

On this, Padilha \& Grande (2011, p. 123) add:

[...] people work to achieve personal goals, such as studying, setting up their own business, qualifying for career advancement, family formation, etc. However, given the great dedication and availability of these professionals to work, an insufficient salary is perceived - mainly for the categories of receptionists and chambermaids. However, the hotels are following what determines the collective agreement of the sector, in relation to the wage floor, which leads us to think that there is a disarticulation between the needs of workers and the agenda of the union that represents them.

It was noted that constant complaints from the interviewed women about the lack of time, excessive work, physical and mental exhaustion revealed that most of their time and energy was used at work. Since the work did not offer what was necessary to maintain the balance between work and family life and also did not pay enough to have exclusivity over the employee, the turnover became greater, because being dissatisfied the employee tended to seek another employment.

It was verified, therefore, that the QWL modified the quality of personal life and that both were related in a bilateral sense. The hotel, which did not provide the means to have a good working environment, did not have enough employees and did not pay its employees adequately, it had a direct impact on the quality of the employees' personal lives. These hotels had a greater number of unmotivated and unsatisfied collaborators, being the notorious the high turnover rate.

All the hotels analyzed sought to establish a QWL in what they considered to be the best, but often forgot that improvements could be produced without much additional cost, establishing a balance between labor rights and motivational factors, supporting their employees in facing the unknown, since at times there was no training; supporting, listening and enabling personal and professional growth; understanding that there is not only the collaborator, but the person, the citizen, the human being.

An exhausting work environment produces stress and increased mental fatigue to the collaborator who, when arriving at home, can not carry out her tasks and have a quality family life. The hotel, which did not have enough employees, demanded a higher workload for the employee and less number of breaks, so that they did not have time for personal life and even when they had it, it was not of a quality, providing relaxation. They were already thinking about the work they would do the next day, as evidenced in the following speech:

I would like to take a little time with the family, that time does not leave, if I go to work on Saturday, I'm already thinking about Sunday, so I mean, your head is not totally quiet, you're not completely satisfied [...] (CZ18, J, 56 years).

It was found that the employees lived in constant internal pressure on their daily work. In addition, offsets happened when the hotel was empty and it was not always when family and friends were also free, restricting that bond. The lack of time also interfered in the maintenance of the health of these 


\section{JOB MARKET}

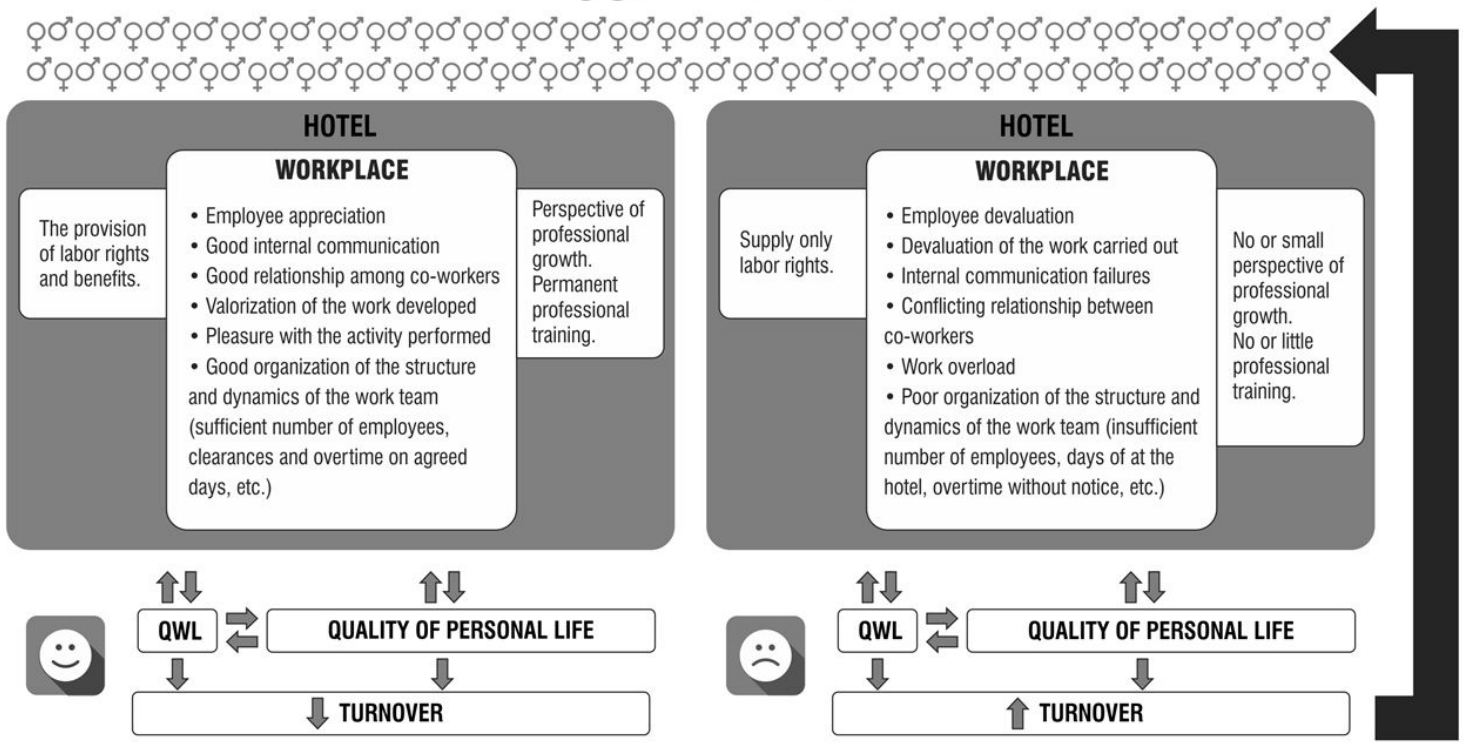

Figure 1. Representative model of the impact of the hotel's positioning on its employees in their turnover. Source: Research data.

women, because many ended up choosing to be with the relatives, to carry out domestic activities or to rest instead of practicing some physical activity. Thus, it was observed how QWL interferes in the quality of personal life of these women and this lived reality interferes directly in the turnover of employees at the hotel.

In relation to the inadequate salary, this generates personal and family problems, since, the poor remuneration limits the person who, even when working, does not produce means to effectively meet the demands of the family, much less have leisure moments such as walks, trips, lunches in family, etc. In addition, it restricts the realization of dreams as the acquisition of own house, mentioned by several collaborators. The salary is a great ally of the employee's permanence in the company, because the first reason to work is to obtain income and if that is not appropriate the employee will look for a new job, thus generating the turnover. Therefore, QWL directly affects personal quality of life.

There are several factors related to QWL that affect personal quality of life and cause employees to turn away from these companies in search of better opportunities. Inadequate personal quality of life also generates dissatisfaction, reflecting in the work environment, at the performance of the collaborator and at the whole team. All the dissatisfaction generated, either by the bad QWL, or by the poor quality of personal life of the employee, leads to turnover in the hotel. It was noted that the turnover was very related to the dissatisfaction with the work environment and the devaluation of the employee.

From the results obtained, the perceptions of the situations experienced by the collaborators of the hotels were outlined and presented in Figure 1.

Thus, the positioning of the hotel in relation to its employees affects its rotation. The hotel, which absorbs manpower from the labor market and provides a healthy and harmonious work environment, provides the labor rights and possible benefits, offers a perspective of professional growth and permanent training, positively influences the QWL and employees personal quality life. In this way, the hotel will have satisfied employees with their QWL and consequently with their personal quality of life, which generates low turnover.

However, the hotel that absorbs the same workforce but does not maintain a good working environment, offering only labor rights, no or little prospect of professional growth and professional training, negatively affects its employees, producing dissatisfaction with the QWL. This affects the quality of personal life. This dissatisfaction reflects in their performance in the hotel, generating turnover and consequently more expenses for the enterprise. This unhappy employee returns to the job market in search of a better opportunity.

\section{Final considerations}

The results showed that the high turnover is closely linked to the company's internal environment, that is, to the harmony of the entire work team and to the 
value of the employee, with the salary, benefits and safety of labor rights being fundamental factors in the employee's permanence in the company.

The fact that they were working already constituted something precious for these collaborators, because it guaranteed a better subsistence of their families and provided sensations about the personal fulfillment.

Another important aspect is the offer of training and qualification of its collaborators in an efficient, periodic and directed way to the different subjects needed. The lack of training of the collaborators reproduces the situation where, the non-investment and valorization of the employee (offering of training / qualification in the activity developed or in related areas), the requirement of execution of a greater number of activities in reduced time, generating greater physical and mental wear, produce dissatisfaction with the work developed and, consequently, greater turnover. Thus, the dismissal of the employee can be caused by his dissatisfaction with the company where he works or due to his non-adaptation to the work developed, which can be due to his lack of qualification.

QWL is directly linked to the employees' personal quality of life. This is due to the interference on the time spent in aspects of personal life, since in periods of great occupation the hotels demanded more permanence and exchange of breaks. In addition, excessive daily work, when the work team is limited, generates physical and mental fatigue impacting on personal quality of life.

The remuneration must be commensurate with the workload, otherwise it will hamper access to better living conditions and, sometimes, the realization of dreams.

In the work there are many factors that influence the motivation and demotivation of the collaborators, characterizing it as something positive or negative, but never only positive or negative. Moreover, when the reconciliation between QWL and personal quality of life is not established in order to provide satisfaction in the work environment and family life, the employee's income, the quality of the services offered by him, his empathy within the company reduces, what, in the case of hotels, is decisive factor in the permanence.

The investigations about QWL and the personal quality of life of collaborators involved in hotel work do not end here, since only a fragment of this vast field was approached. The results found in this study can not be generalized, but it opens the way to new research, analysis and questioning.

\section{References}

Bardin, I. (1994). Análise de conteúdo (p. 226) Lisboa: Edições Setenta.
Branco, G. M., Ribeiro, J. L. D., \& Tinoco, M. A. C. (2010). Determinantes da satisfação e atributos da qualidade em serviços de hotelaria. Revista Produção, 20(4), 576-588.

Brasil. Ministério do Trabalho e do Emprego (2015a). Cadastro Geral de Empregados e Desempregados CAGED. Brasília: Ministério do Trabalho e do Emprego. Retrieved in 2017, Dezembro 22, from http://bi.mte. gov.br/bgcaged/caged_perfil_municipio/index.php

Brasil. Ministério do Trabalho e do Emprego (2015b). Cadastro Geral de Empregados e Desempregados - CAGED. Brasília: Ministério do Trabalho e do Emprego. Retrieved in 2017, Dezembro 22, from http:// bi.mte.gov.br/eec/pages/consultas/evolucaoEmprego/ consultaEvolucaoEmprego.xhtml\#relatorioSubSet

Bom Sucesso, E. P. (1998). Trabalho e qualidade de vida. Rio de Janeiro: Dunya.

Bühler, L. V. (2009). Turnover na hotelaria: estudo de caso da rotatividade de funcionários de uma rede hoteleira de Curitiba (PR) (Dissertação de mestrado). Universidade de Caxias do Sul, Caxias do Sul.

Cândido, Í., \& Vieira, E. V. (2003). Gestão em hotéis: técnicas, operações e serviços. Caxias do Sul: Educs.

Chiavenato, I. (2010). Gestão de pessoas (3a ed.). Rio de janeiro: Elsevier.

Conte, A. L. (2003). Qualidade de vida no trabalho: funcionários com qualidade de vida no trabalho são mais felizes e produzem mais. Revista Faebusiness, 7, 32-34.

Costa, D. S., Balduino, J. C., Pinto, R. F., \& Menezes, P. D. (2011). A mulher no trabalho: a situação de funcionárias da hotelaria de João Pessoa-PB. Revista Iberoamericana de Turismo, 1(2), 36-48.

Duarte, V. V. (2008). Administração de sistemas hoteleiros: conceitos básicos (3a ed.). São Paulo: Editora Senac.

Farias, A. C. (2008). Fatores da satisfação e fidelidade de clientes na hotelaria: um estudo sobre a percepção dos gestores de hotéis (Dissertação de Mestrado). Universidade Federal do Rio Grande do Norte, Natal.

Fernandes, E. (1996). Qualidade de vida no trabalho: como medir para melhorar (3a ed.). Salvador: Casa da Qualidade.

Ferreira, M. C., Alves, L., \& Tostes, N. (2009). Gestão de qualidade de vida no trabalho (QVT) no serviço público federal: o descompasso entre problemas e práticas gerenciais. Revista Psicologia: Teoria e Pesquisa, Brasília, 25(3), 319-327. http://dx.doi.org/10.1590/ S0102-37722009000300005.

Fleck, M. P., Louzada, S., Xavier, M., Chachamovich, E., Vieira, G., Santos, L., \& Pinzon, V. (2000). Aplicação da versão em português do instrumento abreviado de avaliação da qualidade de vida "WHOQOL-bref". São Paulo. Revista de Saude Publica, 34(2), 178-183. http://dx.doi.org/10.1590/S0034-89102000000200012. PMid:10881154. 
Gil, A. C. (2008). Métodos e técnicas em pesquisa social (6a ed.). São Paulo: Atlas.

Höpner, A. (2008). Políticas de recursos humanos e qualidade de vida no trabalho em redes hoteleiras (Dissertação de Mestrado). Universidade Federal do Rio Grande do Sul, Porto Alegre.

Lacaz, F. A. C. (2000). Qualidade de vida no trabalho e saúde/ doença. Revista Ciência \& Saúde Coletiva, 5(1), 151-161. http://dx.doi.org/10.1590/S1413-81232000000100013.

La Torre, F. (2001). Administração hoteleira: departamentos. São Paulo: Rocca.

Magalhães, G. F. O. (2006). Custo humano da atividade, estratégias de mediação e qualidade de vida no trabalho de camareiras em hotel (Dissertação de Mestrado). Instituto de Psicologia da Universidade de Brasília, Brasília.

Medeiros, L. F. R. \& Ferreira, M. C. (2011). Qualidade de Vida no Trabalho: uma revisão da produção científica de 1995-2009. Revista Gestão Contemporânea, 8(9), 9-34.

Medlik, S., \& Ingram, H. (2002). Introdução à hotelaria: gerenciamento e serviços. Rio de Janeiro: Campus.

Mendes, R. A., \& Leite, N. (2008). Ginástica laboral: princípios e aplicações práticas. 2a ed. Barueri: Manole.

Minayo, M. C. S., Hatz, Z. M. A., \& Buss, P. M. (2000). Qualidade de vida e saúde: um debate necessário. Revista Ciência e Saúde Coletiva, 5(1), 7-18.

Minayo, M. C. S., \& Sanches, O. (1993). QuantitativoQualitativo: Oposição ou Complementaridade? Revista Caderno de Saúde Pública, 9(3), 239-262.

Padilha, V., \& Grande, M. M. (2011). “A gente fica muito tempo aqui dentro!": reflexões sobre o trabalho de gerentes, recepcionistas e camareiras de hotéis. Cadernos de Psicologia Social do Trabalho, 14(1), 111-125. http:// dx.doi.org/10.11606/issn.1981-0490.v14i1p111-125.

Pires, C. A. (2007). Qualidade de vida: estudo comparativo entre idosos que frequentam e não frequentam centros de convívio (Trabalho de conclusão de curso). Curso de Psicologia, Universidade Fernando Pessoa, Porto.
Rampazzo, L. (2005). Metologia cientifica: para alunos dos cursos de graduação e pós-graduação (3a ed.). São Paulo: Loyola.

Ribeiro, C. A. O., \& Campos, L. N. M. (2009). Qualidade de vida no trabalho. Revista Tecer, 2(2), 28-39.

Rugiski, M., Pilatti, L. A., \& Kovaleski, J. L. (2005). Qualidade de vida no trabalho: um olhar sobre o tempo livre dos trabalhadores de uma indústria metalúrgica. In Anais do XXV Encontro Nacional de Engenharia de Produção (pp. 1877-1904). Porto Alegre: ENEGEP.

Schmidt, D. R. C. (2009). Qualidade de vida no trabalho e sua associação com o estresse ocupacional, a saúde física e mental e o senso de coerência entre profissionais de enfermagem do bloco cirúrgico (Tese de doutorado). Escola de Enfermagem de Ribeirão Preto, São Paulo. http://dx.doi.org/10.11606/T.22.2009.tde-29062009143214.

Schweitzer, E. (2003). A relação entre a motivação $e$ a rotatividade em uma empresa. Recuperado em 22 fevereiro, 2016 from http://docplayer.com.br/49827A-relacao-entre-a-motivacao-e-a-rotatividade-defuncionarios-em-uma-empresa.html.

Serviço Brasileiro de Apoio às Micro e Pequenas Empresas - SEBRAE. Departamento Intersindical de Estatística e Estudos. (2017). Anuário do trabalho nos pequenos negócios: 2015 (8a ed.). Brasília: DIEESE.

Silva, C. R., Gobbi, B. C., \& Simão, A. A. (2005). O uso da análise de conteúdo como uma ferramenta para a pesquisa qualitativa: descrição e aplicação do método. Organizações Rurais \& Agroindustriais, 7(1), 70-81.

Silva, V. E. (2006). Qualidade de vida no trabalho em uma lavanderia de indústria de abate e processamento de carnes, pela avaliação de riscos ambientais e sócioculturais (Dissertação de mestrado). Universidade Federal de Viçosa, Viçosa.

Zaratini, A. J., \& Padilha, V. (2010). Trabalho e tempo livre: um estudo sobre qualidade de vida no trabalho com gerente do setor hoteleiro. Revista FACEF Pesquisa, 13(2), 204-220. 